\title{
A PÉNZÜGYI TUDATOSSÁG SZEREPE
}

\author{
Levente Kovács - Elemér Terták \\ Financial Literacy - Theory and Evidence \\ Bratislava, 2019 \\ Verlag Dashöfer, 150 p. \\ ISBN: 9788081781209
}

Egy ma születő gyermeknek többet kell tanulnia, mint korábban a szüleinek, hogy boldogulni tudjon az élete

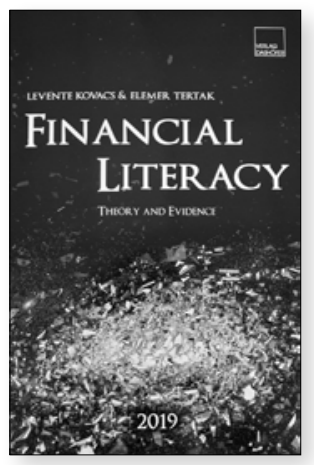
során? Napjainkban szélesebb körü ismeretek szükségesek a világ megértéséhez, mint harminc, száz vagy akár háromszáz évvel ezelőtt? A zsigeri válaszunk az, hogy: igen. Kézenfekvő érvelésként pedig harminc, száz, illetve háromszáz évnyi megismerendő történelemre, kultúrára, tudományos eredményre és technológia fejlődésre hivatkozhatunk (még akkor is, ha a közoktatás sok esetben nem tart lépést az idő múlásával). Ez az információtömeg ráadásul nem az idővel arányosan növekszik - a történelem „sűrüsödik”, egy évtized alatt egy korábbi évszázadnak megfelelő mennyiségű sorsdöntő esemény történhet, innováció, kulturális termék jöhet létre.

Jóval egyszerűbb ugyanakkor az információk elérése és azok megosztása, de helyzetképünknek szükségszerű kiegészülnie napjaink aggasztó, az információfogyasztást megnehezítő tendenciáival is: álhírek, propaganda, közösségi hálózatokban képződő véleménybuborékok, identitáslopások, kiberbűnözés stb. Ezek gátolják a szükséges információkhoz való hozzájutást és azoknak a megfelelő ismeretek birtokában történő logikus rendszerezését, ami a tudatos pénzügyi-fogyasztói döntések meghozatalához is elengedhetetlen lenne.

Ezen folyamatok kifutása megjósolhatatlan, de éppen ezért is fontos a pénzügyi kultúrára ható és az általa meghatározott tényezők megértése, az összefüggések feltárása, az elérhető tudásanyag szintetizálása. Kovács Levente és Terták Elemér Financial Literacy - Theory and Evidence címü kötete érezhetően ennek, illetve az eredmények későbbi gyakorlati alkalmazásának igényével íródott. Ezáltal akár egy gazdasági szakemberek és politikai vezetők számára készült vitaindító avagy döntéselőkészítő dokumentumként is tekinthetünk rá, de tankönyvként, kézikönyvként is remekül hasznosítható, hiszen remekül összegzi a pénzügyi kultúra tudományterületéhez kapcsolódó legfontosabb ismereteket.

A pénzügyi tudás és kultúra szükségességét leginkább gazdasági válságok alkalmával érezzük, ismerjük fel. A hiánytünetek nyomán megjelenő problémák 
ilyenkor nagyságrendekkel kézzelfoghatóbbak. A szerzők is több ízben hangsúlyozzák a válságok és a pénzügyi kultúra összefüggéseit. A 2008-ban kibontakozó pénzügyi krízissel kapcsolatos álláspontjukkal nem nehéz azonosulnunk: a szerzők szerint a korszerü és naprakész pénzügyi ismeretek hiánya kulcsfontosságú szerepet játszott abban, hogy a gazdasági válság a társadalmat szélesebb körben sújtotta, és időben jobban elhúzódott. A subprime válság következményeinek súlyossága elkerülhetetlenné tette a pénzügyi tudatosság gazdasággal való kapcsolatának széles körü felmérésekkel történő elemzését, és a kapott eredmények alapján új akciótervek kidolgozását és megvalósítását, amelyek a jelen és a jövő generációit ellenállóbbakká teszik a feltárt veszélyekkel szemben, illetve a segítségükkel elkerülhetővé válik a múltbéli hibák megismétlése.

A kötet szerzői rávilágítanak arra a tendenciára, amely szerint háborúk, válságok idején és azokat követően a pénzügyi kultúra „divatos” témává válik; ugyanakkor a válságokból való kilábalás során és azt követően a pénzügyi tudatosság szintje jellemzően csökken. Előbbit nemzeti stratégia, valamint különféle kapcsolódó és önálló, a pénzügyi tudatosság fejlesztését célzó programok formájában hazánkban is tapasztalhatjuk, utóbbiról pedig elmondható, hogy azt sajnos igazolni látszanak a kutatások, felmérések. Ez azt is jelenti számunkra, hogy a „divat” elmúltával sem érhet véget a munka, még további hosszú évekre el vagyunk látva kihívásokkal.

A könyv a szerzőpáros korábban megjelent Financial Literacy (Panacea or placebo? - A Central European Perspective ${ }^{1}$ ) címü munkájának átdolgozott, bővített kiadása. Az aktualizált és kiegészített részeken túl a kötet szerzői addicionális fejezetek formájában több fontos új témát is érintenek, például az üzleti (banki) etikát vagy a negatív kamatlábaknak a pénzügyi oktatásra gyakorolt hatását.

A pénzügyi kultúra témakörében született korábbi hazai és külföldi publikációkkal ellentétben, a szóban forgó könyv nem kérdőíves felméréseken alapuló kutatási eredmények bemutatását célozta: létrehozásával a szerzők egy igen szerteágazó területet átfogó, ugyanakkor lendületes és olvasmányos szakkönyvvel örvendeztették meg az olvasókat.

Úgy gondolom, hogy olvasói pedig diákok, pénzügyi szakértők, a politikát meghatározó módon alakító döntéshozók és érdeklődő átlagemberek egyaránt lehetnek - ezt a kötetet megelégedésükre és hasznukra forgathatják. A Miskolci Egyetem Nemzetközi Pénzügy Tanszékén a Financial Literacy címü könyvet a Pénzügyi kultúra tantárgy egyik legfontosabb szakirodalmaként fogjuk alkalmazni.

Pál Zsolt

1 Kovács, L. - Terták, E. (2016): Financial Literacy (Panacea or placebo? - A Central European Perspective). Bratislava: Verlag Dashöfer, 112 p. ISBN: 9788081780165. 